\title{
Analisis Enterprise Architecture Menggunakan COBIT 5 - APO03.01 dan APO03.02
}

http://dx.doi.org/10.28932/jutisi.v6i1.2383

\author{
Diana Trivena Yulianti ${ }^{\# 1}$, Adelia ${ }^{\varpi * 2}$, Giovanni Matthew Reynaldo ${ }^{\# 3}$

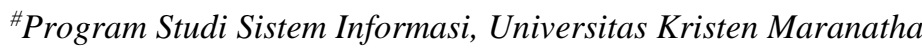 \\ Jl. Prof. Drg. Surya Sumantri no. 65, Sukawarna, Bandung \\ ${ }^{1}$ diana.trivenaeit.maranatha.edu \\ 2adelia dit.maranatha.edu \\ ${ }^{3}$ giovannireynaldo@gmail.com
}

\begin{abstract}
Enterprise architecture design in organizations is one way to find out the information technology used by organizations today, especially in PT. Manufaktur Rak Gondola. PT. Manufaktur Rak Gondola uses the TOGAF 9.1 framework in designing the organization's corporate architecture. Enterprise architecture management analysis aims to ensure that all components that support the process are running well, are identified and functioning properly. The analysis carried out at the same time as the enterprise architecture design process, it will improve the quality of the resulting enterprise architecture design. The results of the analysis can be used as recommendations for adequate control in the running process. The design process that has been carried out, was analyzed using COBIT 5, APO03.01, and APO03.02. The analysis was carried out to ensure compatibility of the TOGAF framework with the controls found in COBIT 5.
\end{abstract}

Keywords - APO03.01, APO03.02, COBIT 5, Enterprise architecture, TOGAF 9.1

\section{Pendahuluan}

Penerapan teknologi informasi pada organisasi, dapat membantu organisasi dalam menjalankan proses bisnis organisasi. Pemetaan dan penggambaran teknologi informasi yang digunakan oleh organisasi merupakan hal yang penting, guna membantu organisasi mengetahui kondisi tekonogi Informasi yang digunakan saat ini. Penggambaran mengenai teknologi informasi dilengkapi dengan prespektif strategi dan bisnis pada kondisi saat ini dan masa yang akan datang, terdapat dalam enterprise architecture (EA) [1]. Pada penelitian yang berjudul Perancangan Enterprise Architecture Menggunakan TOGAF di Universitas ABC, dalam merancang arsitektur bisnis dan sistem informasi diperlukan dukungan dan memaksimalkan penggunaan sistem informasi atau teknologi informasi pada perencanaan enterprise architecture teknologi informasi [2]. Enterprise architecture dirancang untuk PT. Manufaktur Rak Gondola, guna mengetahui gambaran teknologi informasi yang telah dimiliki saat ini.

PT. Manufaktur Rak Gondola merupakan sebuah organisasi yang bergerak dalam bidang industri manufaktur rack atau gondola untuk kebutuhan penataan barang pada toko, minimarket, swalayan dan gudang. Proses bisnis yang berjalan dalam organisasi antara lain proses keuangan manufaktur, pemasaran dan penjualan. Beberapa proses bisnis dalam organisasi telah didukung oleh penggunaan teknologi informasi dalam bentuk aplikasi komputer. Pemanfaatan teknologi informasi yang dilakukan oleh organisasi saat ini belum terarah dengan baik dan data-data yang dibutuhkan belum terintegrasi antar bagian. Menyadari akan pentingnya gambaran mengenai penerapan teknologi informasi pada organisasi, maka dijalankan proses perancangan enterprise architecture menggunakan salah satu framework enterprise architecture yaitu The Open Group Architecture Framework 9.1, yang selanjutnya akan disingkat dengan TOGAF 9.1.

Tahap pertama perancangan enterprise architecture meliputi preliminary phase sampai dengan phase $\mathrm{E}$ Opportunities and Solutions. Pada tahap perancangan enterprise architecture dilakukan analisis audit manajemen enterprise architecture dengan menggunakan Control Objective for Information and Related Technology 5, yang selanjutnya akan singkat dengan COBIT 5.

Audit manajemen enterprise architecture pada proses perancangan enterprise architecture bertujuan untuk memastikan semua komponen yang mendukung proses berjalan dengan baik, enablers teridentifikasi dan berfungsi dengan baik. Audit dijalankan bersamaan dengan proses perancangan enterprise architecture sehingga dapat memastikan penerapan enablers yang mencapai tujuan teknologi informasi. Tujuan penelitian ini adalah menjalankan kegiatan audit manajamen enterprise architecture menggunakan framework COBIT 5 Proses APO03.01, APO03.02. Tujuan lainnya adalah memastikan 
kesesuaian framework TOGAF dengan kontrol-kontrol pada APO03.1 dan APO03.2 pada Framework COBIT 5.

\section{KAJIAN TEORI}

\section{A. Penelitian Terdahulu}

Penelitian dengan menggunakan framework The Open Group Architecture Framework (TOGAF) dan Control Objective for Information and Related Tehnology (COBIT) pada organisasi terlah dilakukan pada beberapa penelitian. Pada penelitian yang berjudul Analisa Penerapan TOGAF dan COBIT Dalam Tata Kelola Teknologi Informasi Sebagai Usulan Pada Kementrian Energi dan Sumber Daya Mineral, TOGAF digunakan untuk mengimplementasikan perencanaan arsitektur informasi yang bersifat generik. Pada TOGAF terdapat panduan untuk mendefinisikan arsitektur data, aplikasi, teknologi dan bisnis. Framework COBIT digunakan untuk mendukung penetapan standar kebijakan dan sebagai kerangka dasar dalam penggunaan teknologi iniformasi. COBIT membantu dalam perencanaan strategis sampai dengan implementasi architecture framework process [3]. Penelitian yang telah dilakukan dan penelitian ini memiliki keterkaitan dalam penggunaan framework TOGAF dan COBIT, yang dapat digunakan untuk menganalisis enterprise architecture dan perencanaan strategis.

Penelitian lain yang telah dilakukan adalah penelitian dengan judul Analisa Tata Kelola E-Government Pemerintah Kota Salatiga Menggunakan Framework COBIT 5 Domain APO. Penelitian ini membahas domain APO01 sampai dengan APO13 yang menjadi fokus penelitian. Pada domain APO03, dilakukan analisis mengenai outcome yang dihasilkan yaitu enterprise architecture yang dapat digunakan untuk mendukung strategi orgnisasi dan teknologi informasi. Proses analisis yang telah dilakukan memberikan gambaran bahwa untuk mendukung proses APO03, organisasi dapat menyusun enterprise architecture dengan menggunakan framework seperti TOGAF dan FEAF [4]. Penelitian ini juga membahas keterhubungan framework COBIT dan enterprise architecture pada domain APO03.

\section{B. Enterprise architecture}

Enterprise architecture memiliki definisi sebagai proses analisis dan dokumentasi sebuah organisasi pada kondisi saat ini dan masa depan, yang ditinjau dari perspektif strategi, bisnis dan teknologi yang terintegrasi. Enterprise architecture merupakan praktik manajemen dan teknologi yang ditujukan untuk meningkatkan kinerja organisasi, dengan meninjau keadaan organisasi dalam hal pandangan holistik dan terpadu dari arah strategis, praktik bisnis, aliran informasi, dan sumber daya teknologi [1].

Enterprise architecture juga dapat didefinisikan sebagai penggambaran pandangan tingkat tinggi dari proses bisnis organisasi dan sistem informasi organisasi. Menggambarkan keterhubungan dan sejauh mana proses dan sistem informasi dibagi dalam beberapa bagian organisasi. Tujuan utama Enterprise architecture adalah untuk menentukan keadaan organisasi yang diinginkan di masa depan proses bisnis dan sistem informasi, atau sering disebut juga arsitekture target dan juga untuk menyediakan gambaran dalam mencapai target dengan menggambarkan keadaan saat ini, atau sering disebut arsitektur dasar [5].

Pengertian lain dari enterprise architecture adalah kumpulan prinsip, metode dan model yang bersifat masuk akal yang digunakan untuk mendesain dan merealisasikan sebuah struktur organisasi enterprise, proses bisnis seperti perencanaan bisnis dan operasional bisnis, sistem informasi dan infrastruktur [6]. Enterprise architecture juga dapat disimpulkan sebagai blueprint organisasi yang menentukan bisnis, informasi dan teknologi yang digunakan agar misi organisasi dapat tercapai [7]. Enterprise architecture adalah dasar aset informasi strategis, yang mendefinisikan misi bisnis, informasi yang diperlukan untuk mencapai misi, teknologi yang dibutuhkan untuk mencapai misi, dan transisi proses untuk mengimplementasikan teknologi baru sebagai jawaban terhadap kebutuhan perubahan misi [8].

\section{The Open Group Architecture Framework (TOGAF)}

TOGAF memandang enterprise architecture ke dalam empat kategori antara lain [9]:

1. Business Architecture, mendeskripsikan tentang bagaimana proses bisnis untuk mencapai tujuan organisasi.

2. Data Architecture, penggambaran bagaimana penyimpanan, pengelolaan dan pengaksesan data pada organisasi.

3. Application Architecture, merupakan pendeskripsian bagaimana aplikasi tertentu didesain dan bagaimana interaksinya dengan apikasi lainnya.

4. Technical Architecture, gambaran mengenai infastruktur hardware dan software yang mendukung aplikasi dan interaksinya.

Pada TOGAF terdapat bagian Architecture Development Method, selanjutnya akan disebut dengan ADM, yang di dalamnya terdapat sembilan tahapan yang harus ditempuh, mulai dari architecture vision sampai dengan requirements management. Tahapan atau bagian yang harus dilakukan atau dilaksanakan adalah [9]:

1. Preliminary Phase

Tahapan atau bagian ini mendefinisikan persiapan kegiatan yang dibutuhkan dan perlu dilakukan. guna memenuhi kerangka arsitektur organisasi, spesifikasi dan prinsip-prinsip organisasi.

2. Phase A: Architecture Vision

Tahapan atau bagian ini mendefinisikan ruang lingkup atau besarnya lingkup pembuatan enterprise architecture, identifikasi stakeholder, dan menciptakan visi arsitektur.

3. Phase B: Business Architecture 
Tahapan atau bagian ini mendefinisikan dan mengembangkan arsitektur bisnis guna mendukung visi arsitektur. Pada tahap ini juga dilakukan identifikasi baseline, desain target dan analisis gap pada arsitektur bisnis.

4. Phase C: Information Systems Architectures

Tahapan atau bagian ini mendefinisikan dan mengembangkan arsitektur sistem informasi, yang dibagi menjadi 2 bagian utama yaitu data architecture dan application architecture, yang digunakan untuk mendukung arsitektur bisnis. Pada tahap ini juga dilakukan identifikasi baseline, desain target, dan analisis gap pada arsitektur sistem informasi.

5. Phase D: Technology Architecture

Tahapan atau bagian ini mendefinisikan dan mengembangkan arsitektur teknologi guna mendukung arsitektur sistem informasi. Pada tahap ini juga dilakukan identifikasi baseline, desain target, dan analisis gap pada arsitektur teknologi.

6. Phase E: Opportunities \& Solutions

Tahapan atau bagian ini digunakan untuk mengevaluasi dan memilih alternatif implementasi, identifikasi parameter strategis penilaian berkaitan dengan biaya, dan manfaat mendefinisikan strategi implementasi dan rencana implementasi.

7. Phase F: Migration Planning

Tahapan atau bagian ini menyusun urutan proyekproyek berdasarkan prioritas termasuk penilaian kebergantungan, biaya, dan manfaat dari proyek migrasi. Urutan prioritas akan menjadi dasar implementasi proyek.

8. Phase G: Implementation Governance

Tahapan atau bagian ini menyusun rekomendasi untuk setiap implementasi proyek, menyusun kontrak arsitektur dan melaksanakan keseluruhan proses implementasi, menetapkan organisasi pelaksana untuk proses implementasi sistem, memastikan kesesuaian pelaksanaan proyek dengan arsitektur yang dikehendaki.

9. Phase H: Architecture Change Management

Tahapan atau bagian menetapkan proses arsitektur manajemen perubahan untuk EA baru yang telah selesai diimplementasikan, secara berkelanjutan memonitor perkembangan teknologi dan perubahan organisasi dan menentukan apakah akan dilakukan siklus pengembangan EA berikutnya.

10. Requirements Management

Tahapan atau bagian ini dilakukan proses mengevaluasi proses dari manajemen arsitektur yang diinginkan melalui ADM.

\section{Control Objective for Information and Related Technlogy (COBIT)}

Control Objective for Information and Related Tehnology (COBIT) merupakan sebuah kerangka kerja yang diciptakan oleh ISACA untuk manajemen Teknologi Informasi (TI) dan tata kelola TI. COBIT memiliki orientasi bisnis yang terdiri dari menghubungkan tujuan bisnis dengan tujuan TI, menyediakan matrik dan model kesempurnaan untuk mengukur prestasi, serta mengidentifikasi tanggung jawab terkait bisnis dan pemegang proses TI [10] . COBIT 5 secara eksplisit menganggap bahwa organisasi menganalisis status bisnis organisasi atau keselarasan teknologi informasi dengan cara mendefinisikan tujuan organisasi, tujuan pemetaan organisasi yang berkaitan dengan teknologi informasi dan menggunakan COBIT proses teknologi informasi [11].

COBIT 5 adalah sebuah versi pembaharuan yang menyatukan cara berfikir yang terbaru dalam teknik-teknik maupun tata kelola TI organisasi. Kemudian, COBIT 5 Menyediakan prinsip-prinsip, praktek-praktek, alat-alat analisis yang telah diterima secara umum untuk meningkatkan kepercayaan dan nilai sistem informasi. COBIT 5 dibangun berdasarkan pengembangan dari COBIT 4.1 dengan mengintegrasikan Val IT dan Risk IT dari ICASA, ITIL dan standar-standar yang relevan dari ISO [12].

COBIT 5 berdasarkan pada 5 (lima) prinsip kunci tata kelola dan manajemen TI organisasi yaitu [12]:

1 Pemenuhan kebutuhan Stakeholder.

2 Melindungi titik-titik penting organisasi.

3 Penggunaan sebuah framework terintegrasi.

4 Memungkinkan pendekatan secara bijak.

5 Memindahkan tata kelola dengan manajemen.

\section{E. Assesment Indicators}

Assesment Indicators digunakan untuk menilai apakah atribut proses telah tercapai sesuai penilaian yang dilakukan [13]. Assesment Indicators, memiliki 2 tipe yaitu:

1. Process Capability Attribute Indicators yang digunakan untuk capability levels 1 sampai 5.

Process Capability Attribute Indicators adalah turunan dari setiap atribut proses untuk capability level 1 sampai level 5.

2. Process Performance Attribute Indicators yang digunakan secara khusus untuk capability level 1.

Process Performance Indicators adalah spesifik untuk setiap proses dan digunakan untuk menentukan apakah suatu proses berada pada kemampuan tingkat 1. Performance Indicators ini terdiri dari praktek dasar dan produk kerja dan khusus untuk tingkat 1 [13].

\section{F. Rating Scales}

Rating Scales digunakan penilai untuk menentukan tingkat kemampuan yang dicapai. Diterapkan secara konsisten, kriteria ini memungkinkan setiap penilaian harus didasarkan pada tingkat terstruktur formalitas dan memungkinkan perbandingan penilaian seluruh organisasi atau bahkan pada organisasi yang berbeda [13]. 
Setiap atribut diberi peringkat menggunakan standar skala penilaian yang ditetapkan dalam standar ISO / IEC 15504, peringkat penilaian ini terdiri dari:

1. N-Tidak tercapai. Terdapat bukti yang sedikit atau tidak ada pencapaian atribut didefinisikan dalam proses dinilai ini.

2. P-Sebagian dicapai. Terdapat beberapa bukti dari suatu pendekatan, dan beberapa pencapaian, atribut didefinisikan dalam proses dinilai ini. Beberapa aspek pencapaian atribut mungkin tak terduga.

3. L-Sebagian besar dicapai. Terdapat bukti dari pendekatan sistematis dan prestasi yang signifikan, atribut didefinisikan dalam proses dinilai ini. Beberapa kelemahan yang terkait dengan atribut ini mungkin terdapat dalam proses dinilai.

4. F-Dicapai sepenuhnya. Terdapat bukti dari pendekatan yang lengkap dan sistematis untuk dan prestasi penuh, atribut yang didefinisikan dalam proses dinilai ini. Tidak ada kelemahan yang signifikan yang berkaitan dengan atribut ini ada dalam proses yang dinilai.

\section{G. APO03 Manage Enterprise architecture}

APO03 mengenai Manage Enterprise architecture merupakan proses untuk membangun arsitektur umum yang terdiri dari proses bisnis, informasi, data, aplikasi, dan lapisan arsitektur teknologi secara efektif dan efisien, untuk mewujudkan strategi organisasi dan TI, dengan menciptakan model dan praktik utama yang menggambarkan arsitektur dasar dan target. Menetapkan persyaratan untuk taksonomi, standar, pedoman, prosedur, template dan alat, serta memberikan tautan untuk komponen-komponen ini [14].

Tujuan dari proses APO03 adalah untuk mempresentasikan bagian bangunan yang berbeda, yang membentuk organisasi dan menggambarkan hubungan antara bagian serta prinsip-prinsip yang memandu desain dan masa evolusi, menjelaskan standar, respons dan efisiensi pelaksanaan operasional organisasi dan sasaran strategis [14].

Key management practice pada AP0 03 adalah [14];

1. APO03.01. Develop the enterprise architecture vision

2. APO03.02 Define reference architecture

3. APO03.03 Select opportunities and solutions

4. APO03.04 Define Architecture implementation

5. APO03.05 Provice enterprise architecture services

\section{HASIL PENELITIAN}

Pada proses perancangan enterprise architecture dilakukan analisis menggunakan COBIT5 pada Proses APO03.01, APO03.02. Hasil penilaian analisis yang dilakukan pada tahapan perancangan enterprise architecture adalah sebagai berikut:

1. APO03.01 Develop the enterprise architecture vision:

a. Kontrol: Mengidentifikasi stakeholder kunci dan perannya serta mendefinisikan kebutuhan utama organisasi untuk mengarahkan pada tujuan arsitektur dengan sebaik-baiknya yang bertujuan untuk memenuhi kebutuhan para stakeholder.

Kesesuaian: Sesuai

Bukti: Stakeholder map matrix, yang ditunjukkan pada tabel I.

TABEL I.

STAKEHOLDER MAP MATRIX

\begin{tabular}{|c|c|c|c|c|}
\hline No & Stakeholder & Involvement & Class & Concern \\
\hline 1 & Direktur & $\begin{array}{l}\text { Keterlibatan } \\
\text { nya pada } \\
\text { kegiatan } \\
\text { manajerial } \\
\text { seluruh } \\
\text { aktivitas di } \\
\text { organisasi } \\
\text { kaitannya } \\
\text { dengan } \\
\text { pembuatan } \\
\text { sistem } \\
\text { informasi/ } \\
\text { arsitektur } \\
\text { sistem } \\
\text { informasi }\end{array}$ & $\begin{array}{l}\text { Manage } \\
\text { closely }\end{array}$ & $\begin{array}{l}\text { Menjalankan } \\
\text { aktivitas } \\
\text { organisasi } \\
\text { Mengatur } \\
\text { budget } \\
\text { organisasi }\end{array}$ \\
\hline 2 & $\begin{array}{l}\text { Manajer } \\
\text { Marketing }\end{array}$ & $\begin{array}{l}\text { Keterlibatan } \\
\text { annya pada } \\
\text { aktivitas } \\
\text { penjualan, } \\
\text { pemasaran, } \\
\text { dan } \\
\text { pengiriman } \\
\text { barang } \\
\text { kaitannya } \\
\text { dengan } \\
\text { pembuatan } \\
\text { sistem } \\
\text { informasi/ } \\
\text { arsitektur } \\
\text { sistem } \\
\text { informasi }\end{array}$ & $\begin{array}{l}\text { Keep } \\
\text { Informed }\end{array}$ & $\begin{array}{l}\text { Proses } \\
\text { penjualan, } \\
\text { pemasaran } \\
\text { dan } \\
\text { pengiriman } \\
\text { barang. } \\
\text { Dampak } \\
\text { pembuatan } \\
\text { sistem } \\
\text { informasi } \\
\text { pada proses } \\
\text { penjualan, } \\
\text { pemasaran, } \\
\text { dan } \\
\text { pengiriman } \\
\text { barang. }\end{array}$ \\
\hline 3 & $\begin{array}{l}\text { Manajer } \\
\text { Produksi }\end{array}$ & $\begin{array}{l}\text { Keterlibatan } \\
\text { nya pada } \\
\text { aktivitas } \\
\text { pembelian } \\
\text { bahan baku, } \\
\text { pengaturan } \\
\text { bahan baku } \\
\text { di gudang, } \\
\text { dan proses } \\
\text { produksi } \\
\text { kaitannya } \\
\text { dengan } \\
\text { pembuatan } \\
\text { sistem } \\
\text { informasi/ } \\
\text { arsitektur } \\
\text { sistem } \\
\text { informasi }\end{array}$ & $\begin{array}{l}\text { Keep } \\
\text { Informed }\end{array}$ & $\begin{array}{l}\text { Dampak } \\
\text { pembuatan } \\
\text { sistem } \\
\text { informasi } \\
\text { pada } \\
\text { pembelian } \\
\text { bahan baku, } \\
\text { pengaturan } \\
\text { bahan baku } \\
\text { di gudang, } \\
\text { dan proses } \\
\text { produksi. } \\
\text { Kesiapan } \\
\text { karyawan } \\
\text { terhadap } \\
\text { sistem } \\
\text { informasi } \\
\text { yang baru. }\end{array}$ \\
\hline 4 & $\begin{array}{l}\text { Manajer } \\
\text { Keuangan }\end{array}$ & $\begin{array}{l}\text { Keterlibatan } \\
\text { nya pada }\end{array}$ & $\begin{array}{l}\text { Keep } \\
\text { Informed }\end{array}$ & $\begin{array}{l}\text { Dampak } \\
\text { pembuatan }\end{array}$ \\
\hline
\end{tabular}




\begin{tabular}{|l|l|l|l|l|}
\hline No & Stakeholder & Involvement & Class & Concern \\
\hline & & aktivitas & & sistem \\
& & pencatatan & & informasi \\
& & keuangan & & terhadap \\
& & dan akunting & & keuangan \\
& & organisasi & & dan akunting \\
& kaitannya & & organisasi. \\
& dengan & & \\
& pembuatan & & \\
& sistem & & \\
& informasi/ & & \\
& arsitektur & & \\
& sistem & & \\
& informasi & & \\
& & & \\
\hline
\end{tabular}

Keterangan: Pada stakeholder map matrix, yang ditunjukkan pada tabel I, dijabarkan stakeholder, peran dan keterlibatannya selaras dengan tujuan arsitektur.

b. Kontrol: Mengidentifikasi tujuan organisasi dan arahan strategis dan mendefinisikan batasan yang harus diterima/dihadapi, termasuk batasan keseluruhan dan batasan terkait proyek yang spesifik (waktu, jadwal, sumber daya, dan lainnya). Kesesuaian: Sesuai

Bukti: Definsi business goal, drivers, and constraints.

Beberapa bukti yang berhubungan dengan business goal, drivers and constraints:

Tujuan bersama dalam organisasi ini adalah bagaimana organisasi ini dapat menjadi lebih maju dalam pelayanannya, yaitu organisasi menjadi lebih cepat dalam hal pelayanan dibandingkan kompetitor lainnya. Untuk melakukan hal itu organisasi sudah melakukan berbagai hal seperti:

a. Menggunakan jasa ekspedisi untuk pengiriman luar Jawa.

b. Mendirikan beberapa gudang di luar pulau Jawa.

c. Menggunakan mesin produksi yang lebih cepat dibandingkan kompetitor lainnya.

d. Memiliki armada pengiriman sendiri untuk pengiriman pulau Jawa.

Berdasarkan tujuan yang telah dijelaskan maka business driver yang dimiliki organisasi pada saat ini adalah :

a. Proses produksi yang cepat.

b. Proses pengiriman yang cepat.

c. Pemrosesan purchase order hingga selesai.

Berdasarkan Tujuan dan business driver yang telah dijelaskan yang menjadi constraint untuk mencapai tujuan adalah :

a. Proses pengolahan purchase order menjadi pesanan jadi yang cukup lama dilakukan karena dilakukan secara manual. b. Sering terjadinya miss-communication antara gudang luar pulau Jawa dan kantor pusat dalam hal stok barang.

c. Proses pengiriman yang tidak menentu karena kondisi jalan .

Keterangan: Tujuan organisasi, arahan strategis, dan batasan didefinisikan pada business goal, drivers, and constraints.

c. Kontrol: Menyesuaikan tujuan arsitektur dengan prioritas program strategis.

Kesesuaian: Sesuai

Bukti: Business Goal, Driver, and Constraints dan Capability Analysis.

Bukti yang berhubungan dengan business goal, drivers and constraints telah dijelaskan pada bagian B. Bukti Capability Analysis: organisasi saat ini berfokus pada pengelolaan data yang terintegrasi di seluruh divisi. Tujuannya adalah supaya ada keselarasan data dari seluruh aktivitas di organisasi, yaitu dari hulu ke hilir. Dengan data yang terintegrasi maka informasi yang disajikan lebih akurat sehingga dapat mendukung proses pengambilan keputusan yang terkait dengan datadata tersebut. Penilaian kapabilitas yang akan diukur adalah business capability dan Information Technology (IT) capability. Waktu yang ditargetkan untuk mencapai target capability dari baseline capability adalah antara 18 minggu dipertimbangkan dari adanya kemungkinan untuk pelatihan untuk karyawan dan masa transisi sistem ke sistem informasi yang baru.

Keterangan: Business Goal, Driver, and Constraints diselaraskan dengan business capability dan IT capability.

d. Kontrol: Memahami kemampuan dan tujuan bisnis, kemudian mengidentifikasi alternatif untuk mewujudkannya.

Kesesuaian: Sesuai

Bukti: Capability Analysis, telah dijelaskan pada bagian $\mathrm{C}$.

Keterangan: Pada masing-masing business capability dan IT capability, dirincikan baseline dan targetnya.

e. Kontrol: Menilai kesiapan organisasi dalam menghadapi perubahan.

Kesesuaian: Sesuai

Bukti: Business transformation readiness, yang ditunjukkan pada tabel II.

TABEL II

BUSINESS TRANSFORMATION READINESS ASSESSMENT BUDGET

Business Transformation Readiness Assessment Maturity Model

\begin{tabular}{|l|l|l|}
\hline $\begin{array}{l}\text { Factor : } \\
\text { Bisnis }\end{array}$ & Class : & Budget \\
\hline
\end{tabular}




\begin{tabular}{|l|l|}
\hline Definition & $\begin{array}{l}\text { Komitmen Organisasi untuk } \\
\text { mengeluarkan budget untuk pelatihan } \\
\text { pegawai dan pembeliann barang yang } \\
\text { diperlukan. }\end{array}$ \\
\hline Maturity level & 4 \\
\hline Maturity & $\begin{array}{l}\text { Organisasi sudah ada komitmen untuk } \\
\text { Description } \\
\text { keperluan mengeluarkan budget untuk } \\
\text { barang dan pelatihan pegawai. }\end{array}$ \\
\hline
\end{tabular}

Keterangan: Business transformation readiness, yang ditunjukkan pada tabel II, mengukur kesiapan dari sisi bisnis, sistem informasi, dan teknologi.

f. Kontrol: Mendefinisikan yang menjadi ruang lingkup arsitektur baseline dan arsitektur target, dan memahami bahwa baseline dan target perlu dideskripsikan pada tingkat kedetilan yang sama.

Kesesuaian: Sesuai

Bukti: Business capability dan IT capability, yang ditunjukkan pada tabel III dan tabel IV.

TABEL III

BUSINESS CAPABILITY

\begin{tabular}{|l|l|l|l|l|l|}
\hline $\begin{array}{l}\text { Business } \\
\text { capability }\end{array}$ & Keterangan Baseline Capability & $\begin{array}{l}\text { Nilai } \\
\text { Baseline }\end{array}$ & Keterangan Future Capability & $\begin{array}{l}\text { Nilai } \\
\text { Target }\end{array}$ & Gap \\
\hline $\begin{array}{l}\text { Human } \\
\text { Resource }\end{array}$ & $\begin{array}{l}\text { Tenaga kerja saat ini berjumlah } \\
\text { 26 orang } \\
\text { Tenaga kerja yang bisa } \\
\text { mengoperasikan komputer } \\
\text { dengan baik berjumlah 14 orang }\end{array}$ & 75 & $\begin{array}{l}\text { Dilakukan pelatihan pegawai yang } \\
\text { tersedia ataupun dengan menerima } \\
\text { pegawai baru untuk menggunakan } \\
\text { sistem informasi/aplikasi yang akan } \\
\text { di gunakan }\end{array}$ & 80 & $\begin{array}{l}\text { Kemampuan } \\
\text { karyawan untuk } \\
\text { menggunakan } \\
\text { sistem informasi } \\
\text { yang baru }\end{array}$ \\
& $\begin{array}{l}\text { Kendaraan antar berupa truk } \\
\text { besar 2 unit dan truk kecil } 8 \text { unit } \\
\text { odanya pemakaian tim ekspedisi } \\
\text { dari luar untuk pengantaran } \\
\text { barang hingga ke luar pulau } \\
\text { Jawa } \\
\text { Mobil operasional sejumlah 10 }\end{array}$ & 75 & $\begin{array}{l}\text { Penambahan kendaraan pengantaran } \\
\text { dan gudang di luar pulau agar untuk } \\
\text { urusan pengantaran barang, } \\
\text { sepenuhnya ditangani oleh } \\
\text { organisasi sendiri }\end{array}$ & 80 & $\begin{array}{l}\text { Jumlah } \\
\text { Kendaraan yang } \\
\text { bertambah } \\
\text { Penggantian dari } \\
\text { ekspedisi ke } \\
\text { pengiriman } \\
\text { sendiri }\end{array}$ \\
\hline
\end{tabular}

TABEL IV.

IT CAPABILITY

\begin{tabular}{|c|c|c|c|c|c|}
\hline IT Capability & Keterangan Baseline Capability & $\begin{array}{l}\text { Nilai } \\
\text { Baseline }\end{array}$ & Keterangan Future Capability & $\begin{array}{l}\text { Nilai } \\
\text { Target }\end{array}$ & Gap \\
\hline $\begin{array}{l}\text { Database } \\
\text { yang ada }\end{array}$ & $\begin{array}{l}\text { Saat ini database merupakan } \\
\text { sebuah penyimpanan cloud yang } \\
\text { diakses secara wireless } \\
\text { Data yang disimpan oleh } \\
\text { database adalah data penjualan, } \\
\text { data pegawai } \\
\text { Data yang disimpan masih } \\
\text { merupakan dalam bentuk file } \\
\text { excel dan word }\end{array}$ & 60 & $\begin{array}{l}\text { Database akan di buat dengan } \\
\text { kemampuan untuk terintegrasi antar } \\
1 \text { divisi dengan divisi lainnya } \\
\text { Database akan dibuat menggunakan } \\
\text { Mysql database } \\
\text { Data bisa di akses oleh pihak yang } \\
\text { memiliki hubungan dengan data } \\
\text { tersebut } \\
\text { Database bisa di akses dengan } \\
\text { aplikasi yang akan di buat }\end{array}$ & 80 & $\begin{array}{l}\text { Database yang } \\
\text { masih } \\
\text { menyimpan data } \\
\text { sederhana seperti } \\
\text { word dan excel } \\
\text { Database belum } \\
\text { terintegrasi } \\
\text { sepenuhnya }\end{array}$ \\
\hline Software & $\begin{array}{l}\text { Software yang digunakan adalah } \\
\text { word dan excel untuk pencatatan } \\
\text { data } \\
\text { Masih belum ada aplikasi yang } \\
\text { bisa mengintegrasikan data } \\
\text { secara langsung untuk antar } \\
\text { divisi }\end{array}$ & 60 & $\begin{array}{l}\text { Akan di buat } 1 \text { sistem } \\
\text { infomasi/aplikasi untuk mengurangi } \\
\text { kemungkinan terjadinya kesalahan } \\
\text { dan mempermudah masalah } \\
\text { integrasi data }\end{array}$ & 80 & $\begin{array}{l}\text { Sistem Informasi } \\
\text { yang belum } \\
\text { terintegrasi }\end{array}$ \\
\hline
\end{tabular}

Keterangan:
\begin{tabular}{|l|l|}
\hline Nilai & Keterangan \\
\hline $1-30$ & Sangat kurang \\
\hline $31-50$ & Kurang \\
\hline $51-65$ & cukup \\
\hline $65-80$ & Baik \\
\hline $80-100$ & Sangat Baik \\
\hline
\end{tabular}


Keterangan: Tingkat baseline dan target arsitektur dibahas pada tingkat kedetilan yang sama pada tabel III dan tabel IV.

g. Kontrol: Memastikan dan merincikan prinsipprinsip architecture, termasuk prinsip-prinsip organisasi. Memastikan definisi terkini dan jelas dalam semua area yang ambigu.

Kesesuaian: Sesuai

Bukti: Architecture principles, yang ditunjukkan pada tabel $\mathrm{V}$.

TABEL V.

ARCHITECTURE PRINCIPLES

\begin{tabular}{|l|l|}
\hline Nomor & 1 \\
\hline Nama & $\begin{array}{l}\text { Semua operasi/kegiatan sesuai dengan } \\
\text { Standard Operating Procedure. }\end{array}$ \\
\hline Tipe & Bisnis \\
\hline Penjelasan & $\begin{array}{l}\text { Semua kegiatan yang terjadi harus sesuai } \\
\text { dengan standard yang ada untuk menjaga } \\
\text { pelayanan yang cepat dan tepat kepada } \\
\text { pelanggan. }\end{array}$ \\
\hline Rationale & $\begin{array}{l}\text { Dengan Sesuai dengan standard yang } \\
\text { ada maka hasil akan menjadi sesuai yang } \\
\text { diinginkan dan mengurangi } \\
\text { kemungkinan terjadinya kesalahan. }\end{array}$ \\
\hline implikasi & $\begin{array}{l}\text { Adanya Rangkaian Prosedur yang jelas } \\
\text { untuk melakukan kegiatan. } \\
\text { Adanya pelatihan kepada karyawan } \\
\text { tentang prosedur- prosedur. }\end{array}$ \\
\hline
\end{tabular}

Keterangan: Didefinisikan business principles, data principles, application priceples.

h. Kontrol: Memahami tujuan dan arah strategis organisasi saat ini yang sejalan dengan proses perencanaan strategis untuk memastikan tantangan/ kesempatan arsitektur organisasi terkait dengan bidang IT berdampak pada pengembangan perencanaan strategis.

Kesesuaian: Sesuai

Bukti: Capability analysis, telah dijelaskan pada bagian $\mathrm{C}$.

Keterangan: Pada capability analysis dijabarkan tentang arah strategis organisasi saat ini serta kondisi target sesuai dengan tantangan/ kesempatan arsitektur organisasi terkait dengan bidang IT.

i. Kontrol: Mendefinisikan visi arsitektur berdasarkan ketertarikan stakeholder, spesifikasi kebutuhan berdasarkan kemampuan bisnis, ruang lingkup, batasan, dan prinsip-prinsip. Visi arsitektur didefinisikan sebagai pandangan tingkat tinggi dari baseline dan target architecture.
Kesesuaian: Sesuai

Bukti: Capability analysis, telah dijelaskan pada bagian $\mathrm{C}$.

Keterangan: Pada capability anaysis didefinisikan visi arsitektur berdasarkan ketertarikan stakeholder, spesifikasi kebutuhan berdasarkan kemampuan bisnis, ruang lingkup, batasan, dan prinsip-prinsip

j. Kontrol: Mendefinisikan dalil nilai arsitektur target yang dipercaya, tujuan dan metrics.

Kesesuaian : Sesuai

Bukti: Capability analysis, telah dijelaskan pada bagian $\mathrm{C}$.

Keterangan: Pada capability analysis dijabarkan tentang arsitektur target.

k. Kontrol: Mengidentifikasi risiko perubahan organisasi yang berhubungan dengan visi arsitektur, melakukan penilaian terhadap level risiko di awal dan mengembangkan strategi mitigasi untuk setiap risiko yang penting.

Kesesuaian: Sesuai

Bukti: Business transformation readiness telah dijelaskan pada bagian E.

Keterangan: Pada business transformation readyness dilakukan analisis risiko terkait dengan perubahan organisasi yang berhubungan dengan visi arsitektur.

1. Kontrol: Mengembangkan konsep kasus bisnis arsitektur organisasi, rencana umum, pernyataan kinerja arsitektur, dan otorisasi yang terlindungi untuk inisiasi proyek yang selaras dan terintegrasi dengan strategi organisasi.

Kesesuaian: Sesuai

Bukti: Capability analysis, telah dijelaskan pada bagian $\mathrm{C}$.

Keterangan: Pada capability analysis dijabarkan tentang konsep kasus bisnis arsitektur organisasi, rencana umum, pernyataan kinerja arsitektur, dan otorisasi yang terlindungi untuk inisiasi proyek yang selaras dan terintegrasi dengan strategi organisasi.

\section{APO03.02 Define reference architecture}

a. Kontrol: Menjaga supaya penyimpanan arsitektur yang berisi standard-standard, komponen yang dapat digunakan kembali, bentuk produk, hubungan, keterkaitan, dan pandangan untuk memastikan keseragaman dengan organisasi arsitektur dan pemeliharaannya.

Kesesuaian: Sesuai

Bukti: Process/Event/ Control Catalog, yang ditunjukkan pada tabel VI dan tabel VII.

TABEL VI.

BASELINE PROCES/EVENT/CONTROL CATALOG

\begin{tabular}{|l|l|l|l|}
\hline Process & Event & Control & Product \\
\hline Pembuatan Surat & Masuknya surat permintaan & Penawaran harga sesuai dengan harga & Surat Penawaran. \\
\hline
\end{tabular}




\begin{tabular}{|l|l|l|l|}
\hline Process & Event & Control & Product \\
\hline Penawaran & barang dari pelanggan. & yang diberikan oleh divisi keuangan. & \\
\hline Pengolahan Pesanan & $\begin{array}{l}\text { Masuknya purchase order } \\
\text { dari pelanggan. }\end{array}$ & $\begin{array}{l}\text { Harga disetujui oleh kedua pihak. } \\
\text { Adanya PO dari pelanggan. }\end{array}$ & Pesanan diproses \\
\hline
\end{tabular}

TABEL VII

TARGET PROCES/EVENT/CONTROL CATALOG

\begin{tabular}{|l|l|l|l|}
\hline Process & Event & Control & Product \\
\hline $\begin{array}{l}\text { Pembuatan Surat } \\
\text { Penawaran }\end{array}$ & $\begin{array}{l}\text { Masuknya surat permintaan } \\
\text { barang dari pelanggan. }\end{array}$ & $\begin{array}{l}\text { Penawaran harga sesuai dengan harga } \\
\text { yang diberikan oleh divisi keuangan. }\end{array}$ & surat penawaran. \\
\hline Pengolahan Pesanan & $\begin{array}{l}\text { Masuknya purchase order } \\
\text { dari pelanggan. }\end{array}$ & $\begin{array}{l}\text { Harga disetujui oleh kedua pihak. } \\
\text { Adanya PO dari pelanggan. }\end{array}$ & $\begin{array}{l}\text { Pesanan diproses pada } \\
\text { data Purchase order. } \\
\text { PO dimasukkan ke } \\
\text { dalam sistem } \\
\text { informasi. }\end{array}$ \\
& & & \\
\hline
\end{tabular}

Keterangan: Pada Process/Event/ Control Catalog dicantumkan tentang menjalankan proses dan hasil produknya, yang ditunjukkan pada tabel VI dan tabel VII.

b. Kontrol: Memilih sudut pandang acuan dari penyimpanan arsitektur yang dapat digunakan oleh perancang untuk mencontohkan apa yang menjadi ketertarikan stakeholder, kemudian dipetakan ke arsitektur.

Kesesuaian: Sesuai

Bukti: Business architecture, information system architecture, dan technology architecture, seluruh komponen pada enterprise architecture organisasi

Keterangan: Pada business architecture, information system architecture, dan technology architecture dicantumkan sisi baseline atau acuan saat ini.

c. Kontrol: Untuk setiap sudut pandang, pilih model yang dibutuhkan untuk mendukung pandangan yang spesifik yang dibutuhkan menggunakan perangkat atau metode dan uraian pada tingkat yang sesuai.

Kesesuaian: Sesuai

Bukti: Business architecture, information system architecture, dan technology architecture, seluruh komponen pada enterprise architecture organisasi.

Keterangan: Pada business architecture, information system architecture, dan technology architecture tercantum tentang model yang dibutuhkan untuk mendukung pandangan yang spesifik (business, information system, dan technology)

d. Kontrol: Mengembangkan deskripsi area baseline architectural, menggunakan ruang lingkup dan rincian yang dibutuhkan untuk mendukung target architectural ke tingkat yang relevan, mengidentifikasi kesesuaian architecture building blocks dari penyimpanan arsitektur.

Kesesuaian: Sesuai

Bukti: Driver/Goal/Objective Catalog, yang ditunjukkan pada tabel VIII dan tabel IX.

TABEL VIII

BASELINE DRIVER/GOALOBJECTIVE CATALOG

\begin{tabular}{|l|l|l|l|}
\hline Organization & Driver & Goal & Objective \\
\hline Eksekutif & $\begin{array}{l}\text { Organisasi yang sudah cukup } \\
\text { mapan. }\end{array}$ & $\begin{array}{l}\text { Organisasi menjadi lebih } \\
\text { baik dan cepat dalam } \\
\text { pelayanan. }\end{array}$ & $\begin{array}{l}\text { Mempercepat proses pelayanan } \\
\text { organisasi. }\end{array}$ \\
\hline Marketing & $\begin{array}{l}\text { Proses pemrosesan pesanan } \\
\text { dan pengiriman barang yang } \\
\text { cepat. }\end{array}$ & $\begin{array}{l}\text { Menjadi yang tercepat } \\
\text { dalam pemrosesan } \\
\text { pesanan. }\end{array}$ & $\begin{array}{l}\text { Mempercepat proses pengolahan } \\
\text { pesanan. } \\
\text { Mengintergrasi antara inventory } \\
\text { dengan penjualan dan keuangan. }\end{array}$ \\
\hline Produksi & Proses Produksi yang cepat. & $\begin{array}{l}\text { Proses Produksi menjadi } \\
\text { lebih cepat dan lebih } \\
\text { efisien lagi }\end{array}$ & $\begin{array}{l}\text { Mengintegrasi antara produksi } \\
\text { dengan marketing dan keuangan. }\end{array}$ \\
\hline Keuangan & $\begin{array}{l}\text { Adanya software zahir untuk } \\
\text { akunting. }\end{array}$ & $\begin{array}{l}\text { Proses akunting yang } \\
\text { menjadi lebih efisien }\end{array}$ & $\begin{array}{l}\text { Mengintegrasi antara keuangan, } \\
\text { marketing dan produksi. }\end{array}$ \\
\hline
\end{tabular}


TABEL IX

TARGET DRIVER/GOAL/OBJECTIVE CATALOG

\begin{tabular}{|l|l|l|l|}
\hline Organization & Driver & Goal & Objective \\
\hline Eksekutif & $\begin{array}{l}\text { Organisasi yang sudah cukup } \\
\text { mapan. }\end{array}$ & $\begin{array}{l}\text { Organisasi menjadi lebih } \\
\text { baik dan cepat dalam } \\
\text { pelayanan. }\end{array}$ & $\begin{array}{l}\text { Mempercepat proses pelayanan } \\
\text { organisasi. }\end{array}$ \\
\hline Marketing & $\begin{array}{l}\text { Proses pemrosesan pesanan } \\
\text { dan pengiriman barang yang } \\
\text { cepat. }\end{array}$ & $\begin{array}{l}\text { Menjadi yang tercepat } \\
\text { dalam pemrosesan } \\
\text { pesanan. }\end{array}$ & $\begin{array}{l}\text { Mempercepat proses pengolahan } \\
\text { pesanan. } \\
\text { Mengintergrasi antara inventory } \\
\text { dengan penjualan dan keuangan. }\end{array}$ \\
\hline Produksi & Proses Produksi yang cepat. & $\begin{array}{l}\text { Proses Produksi menjadi } \\
\text { lebih cepat dan lebih } \\
\text { efisien lagi dan produk } \\
\text { menjadi lebih variasi lagi. }\end{array}$ & $\begin{array}{l}\text { - Mengintegrasi antara produksi } \\
\text { dengan marketing dan keuangan. } \\
\text { - Memproduksi produk baru. }\end{array}$ \\
\hline Keuangan & $\begin{array}{l}\text { Adanya software zahir untuk } \\
\text { akunting. }\end{array}$ & $\begin{array}{l}\text { Proses akunting yang } \\
\text { menjadi lebih efisien } \\
\text { Proses akunting yang } \\
\text { sudah full melalui aplikasi. }\end{array}$ & $\begin{array}{l}\text { - Mengintegrasi antara keuangan, } \\
\text { marketing dan produksi. } \\
\text { - Membuat atau mempelajari sistem } \\
\text { akunting. }\end{array}$ \\
\hline
\end{tabular}

Keterangan: Pada driver/Goal/ Objective Catalog dijabarkan deskripsi area baseline architectural, menggunakan ruang lingkup dan rincian yang dibutuhkan untuk mendukung target architectural ke tingkat yang relevan, yang ditunjukkan pada tabel VIII dan tabel IX.

e. Kontrol: Memelihara model arsitektur proses sebagai bagian dari deskripsi area baseline dan target. Membakukan deskripsi dan doku'mentasi proses. Mendefinisikan tugas dan tanggungjawab proses para pengambil keputusan, pemilik proses, pengguna proses, tim yang menjalankan proses dan proses lainnya yang melibatkan para stakeholder.

Kesesuaian: Sesuai

Bukti: Business service catalog, yang ditunjukkan pada tabel X dan tabel XI.

TABEL X.

BASELINE BUSINESS SERVICE CATALOG

\begin{tabular}{|l|l|l|}
\hline Organisasi & Business Function & Business Service \\
\hline Eksekutif & Mengatur organisasi & Mengambil keputusan. \\
\hline Marketing & Menjual barang & Mengelola pesanan. \\
& & $\begin{array}{l}\text { Menghubungi pelanggan. } \\
\text { Pengiriman barang dan pemasangan barang. }\end{array}$ \\
\hline Produksi & Memproduksi barang & $\begin{array}{l}\text { Mengelola bahan baku. } \\
\text { Memproduksi barang. }\end{array}$ \\
& & $\begin{array}{l}\text { Mengelola Inventory barang. } \\
\text { Finishing/Quality Check. } \\
\end{array}$ \\
& & Packing Barang. \\
\hline
\end{tabular}

TABEL XI

TARGET BUSINESS SERVICE CATALOG

\begin{tabular}{|l|l|l|}
\hline Organisasi & Business Function & Business Service \\
\hline Eksekutif & Mengatur organisasi & Mengambil keputusan. \\
\hline Marketing & Menjual barang & Mengelola pesanan. \\
& & Menghubungi pelanggan. \\
& & Pengiriman barang dan pemasangan barang. \\
& & Mengelola data PO. \\
& & Mengelola data customer. \\
& & Mengelola data barang cabang. \\
\hline Produksi & Memproduksi barang & Mengelola bahan baku. \\
& & Memproduksi barang. \\
& & Mengelola Inventory barang. \\
& & Finishing/Quality Check. \\
& & Packing Barang. \\
\hline
\end{tabular}




\begin{tabular}{|l|l|l|}
\hline Organisasi & Business Function & Business Service \\
\hline & & Mengelola data Produk/barang. \\
& & Mengelola data Gudang. \\
& & Mengelola data resep. \\
& Mengelola data produksi. \\
\hline
\end{tabular}

Keterangan: Pada business service catalog dijabarkan tentang tugas dan tanggungjawab proses para pengambil keputusan, pemilik proses, pengguna proses, tim yang menjalankan proses dan proses lainnya yang melibatkan para stakeholder, yang ditunjukkan pada tabel X dan tabel XI.

f. Kontrol: Memelihara model arsitektur informasi sebagai bagian dari deskripsi area baseline dan target, sama seperti strategi organisasi untuk mengoptimalkan penggunaan informasi atau pengambilan keputusan. Memelihara data dictionary organisasi yang mendorong pemahaman umum dan classification scheme termasuk informasi tentang kepemilikan data, pendefinisian sistem keamanan yang cocok, dan kebutuhan retensi dan penghancuran data.

Kesesuaian: Sesuai

Bukti: Data architecture, seluruh komponen pada data architecture

Keterangan: Pada data architecture dijabarkan tenang model arsitektur informasi sebagai bagian dari deskripsi area baseline dan target.

g. Kontrol: Memastikan model arsitektur yang konsisten dan akurat, serta menjalankan analisis gap antara baseline dan target. Memprioritaskan gap dan mendefinisikan komponen baru atau dimodifikasi yang harus dikembangkan untuk arsitektur target. Menyelesaikan dampak potensial seperti ketidak sesuaian, ketidakkonsistenan atau ketidakcocokan terhadap arsitektur yang dibayangkan.

Kesesuaian: Sesuai

Bukti: GAP business architecture, information system architecture, dan technology architecture, seluruh GAP dan komponen pada enterprise architecture organisasi.

Keterangan: Pada GAP bussiness architecture, information system architecture, dan technology architecture dijabarkan tentang modifikasi yang harus dijalankan untuk mencapai target arsitektur.

h. Kontrol: Menjalankan review stakeholder secara formal dengan cara melakukan pengecekan terhadap arsitektur yang diajukan dibandingkan terhdap motivasi dasar dari proyek arsitektur dan pernyataan kinerja arsitektur.

Kesesuaian: Sesuai

Bukti: Organization/role catalog, yang ditunjukkan pada tabel XII dan XIII serta actor catalog, yang ditunjukkan pada tabel XIV dan tabel XV.
TABEL XII

BASELINE ORGANIZATION/ACTOR CATALOG

\begin{tabular}{|l|l|}
\hline Organization & Actor \\
\hline Eksekutif & Direktur \\
\hline Produksi & Manajer Produksi \\
& Admin bahan baku \\
& Admin produksi \\
& Admin finishing \\
& Admin gudang \\
& Karyawan produksi \\
\hline
\end{tabular}

TABEL XIII

TARGET ORGANIZATION/ACTOR CATALOG

\begin{tabular}{|l|l|}
\hline Organization & Actor \\
\hline Eksekutif & Direktur \\
\hline Produksi & Manajer produksi \\
& Admin bahan baku \\
& Admin produksi \\
& Admin finishing \\
& Karyawan produksi \\
\hline
\end{tabular}

TABEL XIV

BASELINE ACTOR CATALOG

\begin{tabular}{|l|l|}
\hline Actor & Role \\
\hline Direktur & $\begin{array}{l}\text { Mengelola berjalannya organisasi. } \\
\text { Membuat/mengambil keputusan. }\end{array}$ \\
\hline $\begin{array}{l}\text { Manajer } \\
\text { Produksi }\end{array}$ & Mengelola proses produksi. \\
\hline $\begin{array}{l}\text { Admin bahan } \\
\text { baku }\end{array}$ & $\begin{array}{l}\text { Mengelola bahan baku. } \\
\text { Membeli bahan baku. }\end{array}$ \\
\hline $\begin{array}{l}\text { Admin } \\
\text { produksi }\end{array}$ & $\begin{array}{l}\text { Mengawasi produksi barang. } \\
\text { Mengatur alur produksi barang. }\end{array}$ \\
\hline
\end{tabular}

TABEL XV

TARGET ACTOR CATALOG

\begin{tabular}{|l|l|}
\hline Actor & Role \\
\hline Direktur & $\begin{array}{l}\text { Mengelola berjalannya organisasi. } \\
\text { Membuat/mengambil keputusan. }\end{array}$ \\
\hline $\begin{array}{l}\text { Manajer } \\
\text { produksi }\end{array}$ & $\begin{array}{l}\text { Mengelola data produksi. } \\
\text { Mengelola proses produksi } \\
\text { barang. } \\
\text { Mengelola perancangan produk } \\
\text { baru. } \\
\text { Mengelola data gudang. }\end{array}$ \\
\hline
\end{tabular}




\begin{tabular}{|l|l|}
\hline Actor & Role \\
\hline $\begin{array}{l}\text { Admin bahan } \\
\text { baku }\end{array}$ & $\begin{array}{l}\text { Mengelola bahan baku. } \\
\text { Membeli bahan baku. } \\
\text { Mengelola data bahan baku. }\end{array}$ \\
\hline $\begin{array}{l}\text { Admin } \\
\text { produksi }\end{array}$ & $\begin{array}{l}\text { Mengawasi produksi barang. } \\
\text { Mengatur alur produksi barang. } \\
\text { Mengelola data Produk/barang. }\end{array}$ \\
\hline
\end{tabular}

Keterangan: Pada Organization/role catalog dan actor catalog dijabarkan tentang peran stakeholder, yang ditunjukkan pada tabel XII sampai dengan XV.

i. Kontrol: Menyelesaikan arsitektur area bisnis, informasi, data, aplikasi dan teknologi, dan membuat dokumentasi definisi arsitektur.

Kesesuaian: Sesuai

Bukti: Business use case diagram, information system architecture, dan technology architecture, seluruh komponen pada enterprise architecture organisasi.

Keterangan: Pada Business use case diagram, information system architecture, dan technology architecture dijabarkan arsitektur area bisnis, informasi, data, aplikasi dan teknologi.

\section{KESIMPULAN}

Pada analisis yang dilakukan pada enterprise architecture yang terdapat pada PT. Manufaktur Rak Gondola, dapat disimpulkan bahwa kegiatan analisis manajemen enterprise architecture berdasarkan phase yang telah dijalankan (preliminary phase, phase A, phase B, phase $C$, phase $D$ ) dilakukan dengan menggunakan APO03.01 dan APO03.02. Framework TOGAF dan framework COBIT 5 memiliki kecocokan dalam hal kontrol-kontrol yang dijalankan dan dapat membantu organisasi dalam membuat enterprise architecture yang lebih baik.

\section{DAFTAR PUSTAKA}

[1] S. A. Bernard, An Introduction to Enterprise Architecture Author House, 2012

[2] L. Retnawati, "Perancangan enterprise architecture menggunakan TOGAF di universitas ABC," Jurnal Iptek Media Komunikasi Dan Teknologi, vol. 22 no. 1, pp. 11-20, 2018.

[3] A. Supriatna, "Analisa penerapan TOGAF dan COBIT dalam tata kelola teknologi informasi sebagai usulan pada kementrian energi dan sumber daya mineral," Seminar Nasional Informatika (SEMNASIF), 2010, pp.1-8.

[4] U. Sa'diyah and A. D. Manuputty, "Analisa tata kelola egovernment pemerintah kota Salatiga menggunakan framework COBIT 5 domain APO," Seminar Nasional Teknologi Informasi dan Komunikasi (SENTIKA), 2018, pp. 147-155.

[5] T. Tamm, P.B. Seddon, G. Shanks, \& P. Reynolds, "How does enterprise architecture add value to organisations?," Communication of the Association for Informations System, vol. 28, pp. 141-168, 2011

[6] K. Surendro, Pengembangan Rencana Induk Sistem Informasi, Bandung : Informatika, 2009.

[7] T. O. Group, TOGAS Version 9, San Fransisco: The Open Group, 2009.

[8] E. Tse (2009) Risk management on enterprise architecture and system integration. [Online]. Tersedia http://www.projectperfect.com.au/downloads/Info/whitepaper-enterprise-risk-management.pdf

[9] T. O. Group, TOGAF Version 9.1, The U.S: The Open Group, 2011.

[10] Aradea, A. Yuliana and H. Himawan, "Penerapan change management untuk peningkatan proses bisnis dalam meraih keunggulan kompetitif organisasi," Seminar Nasional Informatika (SEMNASIF), 2010, pp.27-36.

[11] S. D. Haes, W. V. Grembergen and R. S. Debreceny, "COBIT 5 and enterprise governance of information technology: building blocks and research opportunities," Journal of Information Systems, vol. 27, no. 1, pp. 307-324, 2013.

[12] ISACA, COBIT 5, Isaca, 2012.

[13] ISACA, COBIT 5 Process Assessment Model, USA: ISACA, 2013.

[14] ISACA, COBIT 5 Enabling Processes, USA: ISACA, 2012. 